is 8 per cent., or 422.4 feet per mile. The whole line from Buenos Ayres to Valparaiso is 850 miles long, of
which 701 miles were completed and opened at the
last accounts, and the rets: last accounts, and the relw. ning 149 miles were under construction through the mountain section, involving
very heavy work and a large number of tunnels,many of the sea. It is being constructed by English engineer and contractors.

THE HYDRAULIC SLIDING RAILWAY.

Among railroad novelties may be mentioned the
Hydraulic Sliding Railway, a section of which has been opened near the Crystal Palace, in London. This is the same "chemin de fer glissant" which was ex hibited at the Paris Expo The principal feature of this decidedly novel inven-
tion is that it dispenses entirely with wheels, and substitutes therefor a series of iron shoes which carry
the railway car, and rest upon a broad flat rail. The shoes are perforated with a very narrow annular orifice, or as actually to raise the shoes off the rail, and to float the cars upon a very thin water bed betw, and to floa and the rail. 'This, as may be imagined, reduces the resistance to forward motion to a minimum, experiment having shown that this hydraulic friction on the slidusual rolling friction of the wheels on an ordinary rail way. As the whole train is thus afloat on this film of to it from the motize power. This is ingeniously $d$ ? by a series of water jets issuing from fixed nozz maticalty by the train itself, and which impinge upon suitable pallets attached under the cars. As may be
realized, the consumption of water is great, and other realized, the consumption of water is great, and other
methods of propulsion have been proposed, but thus far without any practical results. This novel system has been mentioned more as a matter of curiosity than as one from which satisfactory results in transportation claim that speeds of 70 to 125 miles an hour have been
obtained, and that no less than 94 per cent. of the fuel required to drive a train can be saved, giving actual experimental figures to prove it. . Such data were evithe resistance on a level is but a very small part of that to be encountered upon a railway. The wheel friction,
for instance, is $41 /$ to 5 pounds per ton, while that from gravity on a grade of 52.8 feet per mile is 20 pounds per ton; and there are in addition the resistance from
curves and from the atmosphere-the latter at high velocities solvering the an importa and possibly for drawbridges, this idea of for cranes, a weight upon a thin film of water, issuing at a great preseure, may be worth experimenting with.

THE SIBERIAN RALWAY.

One of the great railways of the world, which is eventually to be over 5,000 miles llong, is now under ern and Western Siberia. For the present it is to the navigable waters of rivers in the interior. Beginning at the Pacific end, at Vladivostok on the Japan Sea, the first section is to extend 261 miles to the navig-
able waters of the Amour; there to connect with 1,590 miles of steamboat navigation. Thence begins another
railroad section of 1,895 miles more, which again connects with 1,870 miles of steamboat navigation and miles further to St. Petersburg. Altogether there are cost of $\$ 100,000,000 ;$ and the work is expected to be
completed in six years, Russia has now about 20,000 completed in six years, Russia has now about 20,000
miles of railway for some $92,000,000$ inhabitants. If it construction, there may be an opportunity for the employment of the rapid and cheap American methods world. THE RAILWAYS OF THE WORLD.

It may be interesting in this connection to inquire as
o the relative railroad status of various continents, and having lately had occasion, for another address, in the world on the 1 st of January, 1891 , the result is
herewith graphicaliy exhibited by a diagram. On this

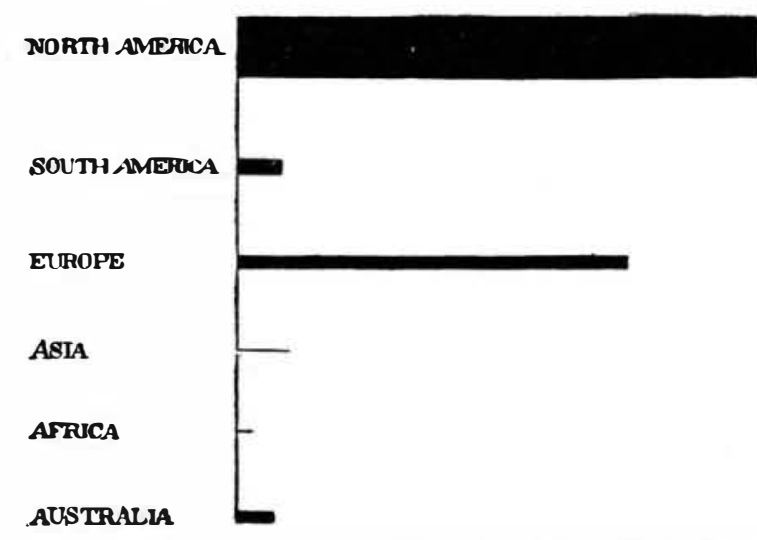

diagram the length of the lines represents the aggregate number of niles on each continent, and the thickness represents the ratio of the number of miles of
railroad for each 10,000 inhabitants. The actual figures are as follows :

or 21.54 miles per 10,000 inhabitants or 21.54 miles per 10,000 inhabitants. South America
to have 16,000 miles, or 5 miles per 10,000 inhabitants while Europe has 141,000 miles, being at the rate of 4 of per 10,000 . Asia having 20,000 miles, or only a ratio
of $\frac{1}{4}$ mile per 10,000 . Africa, with 6,000 miles of rail road, averaging $1^{3}$ of a mile per 10,000 inhabitants, and Australia, ranking nearly with Europe and South more particularly Chinabitants. Asia, therefore, and railroad missionary work, for it cannot fail eventually o ascertain how great a national economy will follow
upon the substitution of railroad for other methods of

There was occasion, in connection with the schedule
of the world's railways already referred to to estimate this national economy for the United States, and it cessity for the whole volume of the exchange of commodities and wovements of passengers (which volume, of course, could not exist at the higher charges), the
business done by our railroads in 1889 , at the rates of reight and passengers which existed before the railway era, would have cost the nation not less than $\$ 12,239,-$
899,980, while the charges actually collected were $\$ 999,-$ 856,856 , thus leaving a difference, or national saving on that basis, of $\$ 11,247,043,124$, or more than the entire y their stocks and liabilities, amounted to $\$ 9,931,453$, The average cost of railroads in the United States stands at about $\$ 60,000$ per mile, while in Europe they being largely the result of the cheaper methods and designs which original scarcity of capital and labor have led our engineers to develop. The Americans are now the great railroad builders of the world, they execute such undertakings with less expenditures, as
measured either in money or in day's work, than other nations, and it seems not impossible that firms of
American engineers and contractors slaall find it profitable to employ these wethods in other countries, let the capital, the labor, or the materials come from whence they may.
(To be continued.)

THE ELECTROLYTIC PREPARATION OF CHLORATE OF POTASSIUM.

For the past ten months the manufacture of chlo-

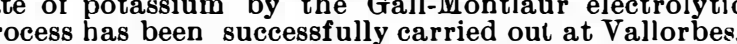
The daily output now amounts to one ton of refined chlorate. According to La Lumiere Electrique, M.
Lunge states that one $\mathrm{H}$. P. a day=one kilogramme of potassic chlorate, hence a daily production of one ton requires $1,000 \mathrm{H}$. P. The process is hased on the transformation of a 25 per cent. solution of chloride of pointo chlorate $\left(\mathrm{KClO}_{3}\right)$ by the action of the chlorine and potasium liberated by electrolysis. The chlorate is
presipitated, collected, washed, dried and purified. One of the preliminary difficulties was the selection of est trace of certain metallic oxides in the solution ar being in use at one time) vats are 270 in number (half ranged so as to permit of the rapid handling of the
volume of liquid, amounting'to 11,000 gallons per diem. volume of liquid, amounting'to 11,000 gallons per diem
A porous diaphragm separates the cathodes from the anodes, the former being of iron and the latter of plaproper temperature by the current itself. Power is obtained from the falls of the Orbe, which can supply $2,500 \mathrm{H}$. P. At present there are installed at the gene-
rating station ten $150 \mathrm{H}$. P. Riether turbines, and rating station ten $150 \mathrm{H}$. P. Riether turbines, and
105-kilowatt Thury dynamos. Thegenerating plant is at the foot of a mountain, the works themselves being This arrangement has the $t$ wofold advantage of obtaining a great head of water and of removing the machinery out of reach of the fumes given off in the pro3,530 cubic feet per ton of chlorate turned out, and as with it a certain amount of chloride of potassium icinity of the works is covered with a thick. white saline deposit of a highly erosive character. With ample water power available, the electrolytic process can un-
dersell the chemical process, although at present only 400 tons per annum is being produced by it, as against
8,000 tons by the older method. Some 5,000 tons of thi 8,000 tons by the older method. Some 5,000 tons of this
total is produced by the works of the Chemical Union. total is produced by the works of the Chemical Union.
The electrolytic process is cleaner, simpler, quicker, leaves no
purposes.

\section{POCKET ELECTROMETERS.}

By C. V. BoYs, F.R.S.

As quartz fibers increase the delicacy and diminish the disturbing influences affecting instruments, much
sinaller controlling forces can be employed than when
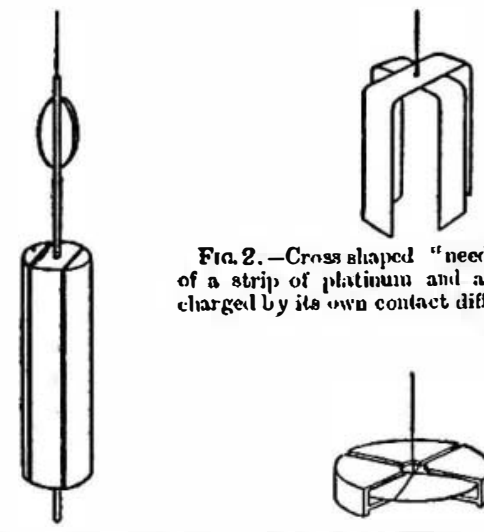

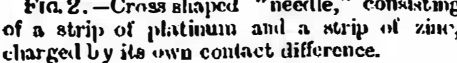

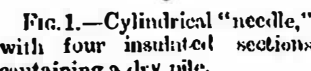

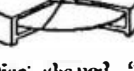

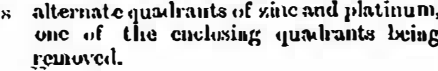
silk is used for suspensions. The author had, he said, from making galvanometers small. Applying similar reasoning to electrometers, he remarked that making reduced the moment of inertia of the needle to $1 \frac{1}{16}$, while the deflecting couple for given potentials would
only be $\frac{1}{10}$ of its former value. The small instrument would, for the same periodic time, be 10,000 times more
sensitive than the large one, provided the disturbing influences could be reduced in the same proportion.
This, however, was not ordinarily possible, for an winod of making contact with the needle such as by anall controlling forces being used. Still, by suitable devices, a large proportion of the full advantage could contacts was essential to success. The first instrument escribed was one in which the needle was cylindrica (Fig. 1), contiguous quarters being insulated and con within the needle; opposite quarters were then at th same potential, and at a different potential to the other
pair of quarter cylinders. This was suspended within 政 nstrument the needle and and the deflection depends on the product of the difference of potential between the quadrants and that
between the parts of the needle. Owing to the dry pile not being constant, the instrument was found un would give 30 or 40 millime ars deflection. The cel step was to make a cross shaped needle of zinc and platinum (Fig. 2), and rely on contact electricity to his bold experiment proved remarkably successful or the instrument was very sensitive. A disk-shaped was then employed, and by this a small fraction of a volt could be measured. The weight of the disk was only $\frac{1}{20}$ of a gramme, and the instrument could be turned npside down or carried about in the pocket
with impunity. Another small instrument with the quadrants of zinc and copper (Fig. 3) was exhibited, as to bring them in a different position relative to the arts of the needle, a deflection of several degrees of relating to ballistic electrometers and electrostatic Sie mens dynamometers, and pointed out the possibility of instruments such as he had exhibited being of use
in elucidating the obscure points in connection with
so-called "contact electricity."-The Electrician

THE EDISON PATENT DECISION.

IN July, at New York, Judge Wallace filed his patent suit of the Edison Electric Light Company Lighting Company was made before him a month ago on the Edison patent
No. 223,898 for an incandescent electric lamp, and took eight days. The printed testimony fills seven volumes
or about 6,000 pages. The taking of the testimony had ept the lawyers on both sides busy almost continuous of counsel on both sides are eight in number, covering fills 23 pages of typewritten legal cap, and sweepingly ng being ordered.
Edisor's invention was made in 1879 , and his paten as granted in 1880. The suit was begun in 1885 , th subject in controversy being two claims of the letters
patent No. 223,898, "for an improvement in electric amps." These two claims were as follows 1. An electric lamp for giving light by incandescence, made as described, and secured to metallic wires, a set forth

2. The combination of carbon filaments with a re through the glass, and from which receiver the air is exhausted for the purposes set forth. Judge Wallace decides that the defendant does not
nf ringe the first claim, because the leading wires in its amps are not secured to the filament according to the method of the patent, but, on the second claim, judg
ment is given for the plaintiff, that being in reality the Edison Company. The following is the most important part of th The second claim is broad enough in its phraseology to secure the real invention described in the specification, and can be read consistently with its language so It was a remarkable discovery that an attenuated perfect vacuum. The extreme fragility of such a structure was calculated to discourage experimentation
with it, and it does not detract in the least from the originality of the conception that previous patent bridges could be used. The futility of hoping to maintain a burner in vacuo with any permanency had discouraged prior inventors, and Mr. Edison is entitled which disheartened them, but what he did in this re spect was a matter of only secondary merit, and was
no longer new in the art, because he had already disWhat he actually accomplished was to unite the characteristics of high resistance, small radiating surface and durability in a carbon conductor by making it in a form for extreme tenuity, out of any such bonizing it, and arranging it as he had previously arranged his platinum burner in an exhausted bulb mose where the leading wires entered, by the fusion of the glass. He was the first to make a of the glass. He was the first to make a carbon of ma-
terials and by a process which was especially designed
to impart high specific resistance to it, the first to make a carbon in the special form for the special pur pose of imparting to it high total resistance, and the jirst to combine such a burner with the necessary ad.
juncts of lamp construction to prevent its disintegration and give it sufficiently long life. By doing these things he made a lamp which was practically operat ive and sucessful, the embryo of the best lamps now
in commercial use, and but for which the subdivision in commercial use, and but for which the subdivision
of the electric light by incandescence would still be nothing but the ignis fatuus which it was proclaimed
to be in 1879 by some of the learned experts who are
now witnesses to belittle his achievement and show that it did not rise to the dignity of an invention. 